\title{
Study of the Tribological Properties of Paraffin and Polyethylene Wax as Antiwear Additives in refined Sesame Oil
}

\author{
Estudio de las Propiedades Tribológicas de la Parafina y Cera Polietilénica como \\ Aditivos Antidesgaste en Aceite de Ajonjolí refinado
}

\author{
A. E. Delgado-Tobón iD, W. A. Aperador-Chaparro iD, E. Rodriguez-Carmona iD
}

\begin{abstract}
Resumen-Los aceites de origen vegetal fueron una de las principales fuentes de aceites lubricantes antes de la aparición del petróleo. Actualmente, debido a la baja estabilidad térmica y a la oxidación, no se emplean con la misma frecuencia en el sector industrial. Sin embargo, los diferentes ácidos grasos que componen los aceites vegetales pueden reducir significativamente el coeficiente de fricción. Para optimizar la lubricación, el aceite vegetal puede ser mezclado con aditivos. En esta investigación, se realizó un estudio comparativo del poder lubricante del aceite de Ajonjolí con Cera polietilénica y Parafina como aditivos. Esta propiedad, fue evaluada mediante ensayos de desgaste preventivo y presión extrema en un tribómetro cuatro bolas. Los resultados experimentales, mostraron que para la prueba de desgaste preventivo D.P la mezcla con cera polietilénica, presenta el menor diámetro promedio de huella, mientras para la prueba de extrema presión E.P la mezcla con parafina dio una mayor resistencia a la carga aplicada, obteniendo un punto de soldadura a $32 \mathrm{Kg}-\mathrm{F}$ (314N) siendo mayor que para el aceite y con cera polietilénica $(24$ $\mathrm{Kg}-\mathrm{F}(\mathbf{2 3 5 N}))$. En relación al coeficiente de fricción los resultados obtenidos muestran que no existe diferencia entre el aceite y las mezclas con los diferentes aditivos. A partir de estos resultados, se puede concluir que el rendimiento del aceite de ajonjolí como lubricante, se puede mejorar mediante su mezcla con parafina y cera polietilénica, sin embargo, los porcentajes añadidos deben determinarse correctamente.
\end{abstract}

Palabras claves - Aceite vegetal, Cuatro bolas, Extrema Presión, Desgaste Preventivo.

Abstract-Vegetable oils were one of the main sources of lubricating oils before the appearance of oil. Currently, due to low thermal stability and oxidation, they are not used with the same frequency in the industrial sector. However, the different fatty acids that make up vegetable oils can significantly reduce the

This manuscript was sent on August 8, 2019 and accepted on December 19, 2019.

The authors thank the Universidad Militar Nueva Granada for their support. Arnoldo Emilio Delgado Tobón, asociate professor, Engineering Faculty, Universidad Militar Nueva Granada. Career 11 No. 101-80 Bogotá D.C., Colombia. (e-mail: arnoldo.delgado@unimilitar.edu.co)

William Arnulfo Aperador Chaparro, titular professor, Engineering Faculty, Universidad Militar Nueva Granada. Career 11 No. 101-80 Bogotá D.C., Colombia. (e-mail: william.aperador@unimilitar.edu.co) coefficient of friction. To optimize the lubrication, vegetable oils can be mixed with additives. In this research, a comparative study of the lubricating power of sesame oil with polyethylene wax and paraffin as additives was carried out. This property was evaluated by preventative wear tests and extreme pressure in a four-ball tribometer. The experimental results showed that for the preventive wear test the mixture with polyethylene wax has the smallest average diameter of the fingerprint, while for the extreme pressure test the mixture with paraffin gave a greater resistance to the applied load, obtaining a welding point to $32 \mathrm{Kg}-\mathrm{F}$ (314N) being greater than for pure oil and with polyethylene wax $(24 \mathrm{Kg}$ $F(235 \mathrm{~N}))$. In relation to the coefficient of friction the results obtained show that there is no difference between the oil and the mixtures with the different additives. From these results it can be concluded that the yield of sesame oil as a lubricant can be improved by mixing it with paraffin and polyethylene wax; however, the percentages added must be determined correctly.

Index Terms - Extreme Pressure, Four balls, Preventive wear, Vegetable oil.

\section{INTRODUCTION}

$\mathrm{D}$ Ifferent types of lubricants are available in the world, among which these are mineral, synthetic, refined and vegetable oils. Most of these lubricating oils are available on the market and are based on mineral oils, which come from petroleum derivatives, and for this reason they are not environmentally friendly due to their high toxicity and low biodegradability $[1,2]$.

Vegetable oils are widely used as lubricating bases. These are triglycerides whose glycerol fragment is composed by three hydroxyl groups esterified with carboxyl groups of the fatty acids [3]. These fatty acids are unsaturated and with a carbon

Esperanza Rodríguez Carmona, associate professor,Engineering Faculty, Universidad Militar Nueva Granada. Career 11 No. 101-80 Bogotá D.C., Colombia. (e-mail: esperanza.rodriguez@unimilitar.edu.co) 
chain that depends on the oil they are linked into the hydroxyl group by ester bonds [4]. Currently, many countries seek various types of vegetable oils that can be used as lubricants. In Malaysia, palm oil is the focus of development as an industrial oil. Palm oil is the only one that can be refined in various types of oil: refined, bleached and deodorized (RBD), where palm olein is the most important component and is used as a cooking oil. Other typical vegetable oils that have the potential to create lubricants are Jatropha and coconut oil [5].

The main limitations of these have been their high cost, low thermal stability and oxidation [6]. Therefore over the years various types of additives have been studied in order to increase and improve the chemical properties of vegetable oils, turning them into products capable of competing with the widely used mineral oils. Many of the additives used, while having good anti-wear properties, pollute the environment; among these is di-butyl 3,5-di-t-butyl 4-hydroxybenzylphosphonate (DBP), which according to studies has an excellent anti-wear performance compared to the conventional tricalcium phosphate (TCP) additive under high speed and temperature conditions [6]. At the same time, thiophosphates, tri-noctylthiophosphate and tri-n-octyltetrathiophosphates in appropriate concentrations show better tribological properties but increase the coefficient of friction of the base material at certain concentrations [7]. Other studies show that the addition of $2 \%$ (by weight) of Zinc-dialkyl-Dithio-phosphate (ZDDP) significantly improves the behavior of coconut oil [8]. Chemically synthesized additives as xanthate derivatives of thiophen, including [S- (2H-thiophen-2-yl) -methyl] ethylxanthate (TMEX), [S- (2H-thiophen-2-yl)] -methyl-butyl xanthate (TMBX) and [S- ( 2H-thiophen-2-yl)] - xanthamethyloctyl (TMOX), improve the anti-wear properties, reduce friction and significantly increase the load capacity of the base oil [7]. Studies in modified olive oil show that the mixture of Amino phosphonate (additive A) and commercial antimony dithiocarbamate (additive B) in concentrations of $6 \%$ decreased wear [9].

Due to the toxicity and low degradation capacity of the aforementioned additives, new alternatives have been studied that can improve the anti-wear power of vegetable oils and at the same time contribute to the preservation of the environment. Among these investigations can be mentioned those made by Quinchia [10], in which different types of vegetable oils (sunflower, soybean and castor), were mixed with $4 \%$ EVA that helps to reduce friction and wear and $1 \% \mathrm{EC}$ that improves the mixed lubrication and limit. Other studies show that the synthesis of various phosphorus-free products and triazine derivatives, such as 2,4,6-trioctylthio-1,3,5-triazine (OTT) and octylthiol (OT), can improve the carrying capacity and significantly reduce friction [11]. In rapeseed oil, the addition of $1.5 \%$ by weight of ZOS, ZOO and ZDION reduces the coefficient of friction (f) [12]. In this same oil [13], 2,4,6-tri [N, N-di-n-butyldithiocarmate- (2'-hydroxyl) -propionylthio] 1,3,5-s- triazine (LDBA) and 2,4,6-tri [N, N-di-ioctyldithiocarmate- (2'-hydroxyl) -propionylthio] -1,3,5-striazine (LDIOA) have been used, obtaining an improvement in the anti-wear property.

Another class of synthetic additives with ecological potential that have been studied, derived from S- [2- (acetamido) thiazol1 -yl] dialkidithiocarbamate, in rapeseed oil have been shown to be effective in reducing wear and increasing the ability to reduce friction [14]. Derivatives of N, Ndialkyldithiocarbamate-S-hydroxyethylborates [15], synthetic heterocyclic derivative of S- [2 (acetamido) benzothiazol-1-yl] $\mathrm{N}, \mathrm{N}$-dithiocarbamate dibutyl [16], derivatives of S- $(1 \mathrm{H}-$ benzotriazol-1-yl) methyl N, N- dialkyldithiocarbamates [17] exhibit good anti-wear and friction-reducing capacity similar to ZDDP.

In this research, the inclusion of two additives (polyethylene wax and paraffin) to sesame oil as modifiers of its lubricating power was evaluated. The tribological properties were carried out according to the four-ball method for the tests of Preventive Wear (PW) and Extreme Pressure (EP).

\section{MATERIALS AND METHODS}

\section{A. Materials}

Refined sesame oil, commercial paraffin, commercial polyethylene wax. To perform the tribological tests were used spheres of steel with chromium alloy AISI 52100, $12.7 \mathrm{~mm}$ in diameter, with hardness of 60-66 HRC. These spheres, according to the commercial certificate, have a chemical composition of: $0.96 \%$ Carbon, $0.33 \%$ Manganese, $0.26 \%$ Silicon, $0.004 \%$ Sulfur, $0.011 \%$ Phosphorus, $1.48 \%$ Chromium, 0.05\% Nickel, 0.110 Copper and $0.0016 \%$ Titanium.

\section{B. Experimental design}

The tests were carried out with a concentration of paraffin and polyethylene wax of $1 \%(\mathrm{w} / \mathrm{w})$.

\section{Tribological tests}

We performed tribological tests of preventive wear (PW) and extreme pressure (EP). These were carried out according to ASTM D 4172-94, with conditions of $75^{\circ} \mathrm{C}, 1200 \mathrm{rpm}$, load of 147 Newtons and time of 60 minutes for preventive wear, evaluating the lubricating power of the oil by measuring the average diameter of the wear fingerprint (DPH) and the coefficient of friction (f). For the Extreme Pressure test, the Load Prior to Visible Wear and the Welding Point were determined, according to ASTM D 2783-03, with conditions of $20^{\circ} \mathrm{C}, 1760 \mathrm{rpm}$, variable loads: $98,127,157,196,235,314 \mathrm{~N}$, each test having duration of 10 seconds. These tests were performed on a four-ball tribometer, and an optical microscope was used to measure the fingerprints.

\section{RESULTS AND DISCUSSION}

\section{A. Preventive Wear Testing ( $P W)$}

There are several types of wear in the mechanical system: abrasive wear, adhesive wear, fatigue wear and corrosive wear. As we are evaluating the lubricating power of sesame oil with added additives, in this experiment the abrasive and adhesive 
wear are observed mainly in the rubbing zone of the spheres used [18].

This is why we evaluated the wear resistance of sesame oil with the additives used in terms of average diameter of the wear fingerprint and the coefficient of friction (f). In Figure 1 the comparison between the values obtained for the average diameter of the wear fingerprint (DPH), measured by means of an optical microscope at the end of the preventive wear test, is presented. According to these results, greater wear is observed on the metallic surface of the spheres that were lubricated with the mixture of sesame oil and paraffin. Figure 2 shows the images of the wear fingerprint, giving further evidence of it.

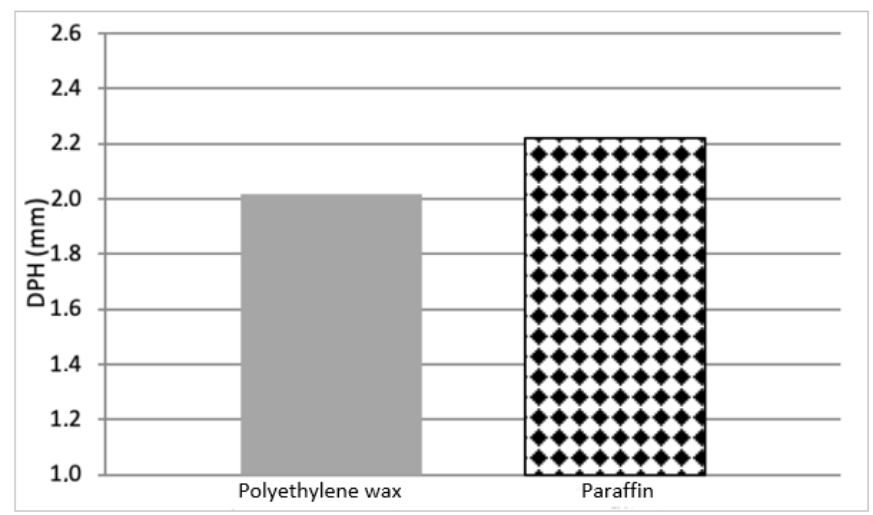

Fig. 1. Average diameter of the wear fingerprint obtained in the preventive wear tests.
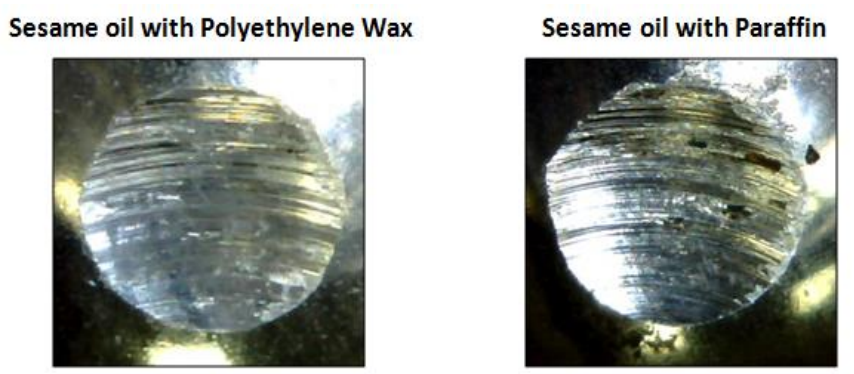

Fig. 2. Diameter of fingerprints. Preventive Wear Test - P.W.

The sesame oil is a triglyceride, composed of a polar part, which is constituted by ester groups, which give it a greater affinity to metal surfaces and therefore an improvement in lubricating power [19]. This occurs because the polar heads form a mono layer with the non-polar end of the fatty acids thus creating a layer resistant to contact with the metal surface; the apolar or hydrocarbon chains of sesame oil (7-12\% Palmitic, 0$0.5 \%$ Palmitoleic, $3.5-6 \%$ Stearic, $35-50 \%$ Oleic, $35-50 \%$ Linoleic, 0-1\% Linolenic and 0-1\% Eicosenoic acids [20] create an anti rub or slippery surface that decreases metal-metal contact [21]. Polyethylene wax has a molecular weight between 2000-8000 with a slightly branched structure [22], which is why there is the interaction between the polar heads and the branched chains of the polyethylene wax, decreasing the metalmetal contact and therefore the resulting fingerprint diameter.

In relation to the coefficient of friction (f), the results obtained presented in Table 1 show little difference between the values of the mixture of sesame oil with paraffin and polyethylene wax. These results were analyzed by the ANOVA test (Table 2) with the software SPSS 11.5 in which a significance of $p \geq 0.05$ was obtained, concluding that there is no significant difference between the values obtained for the two mixtures.

In previous investigations it was demonstrated that vegetable extra virgin oil has a coefficient of friction of 7.1 [23]; according to this, the values of the coefficients of friction for sesame oil and the respective mixtures found were compared using the ANOVA test. Table 3 shows the results of the ANOVA test, finding a significance of 0.220 ( $\mathrm{p} \geq 0.05)$, that is, there is no significant difference between the three coefficients of friction, therefore the amount of paraffin or polyethylene wax added to sesame oil does not represent an improvement in oil wear properties.

TABLE I

COEFFICIENTS OF FRICTION, PREVENTATIVE WEAR TEST.

\begin{tabular}{lc}
\hline \hline \multicolumn{1}{c}{ Mixture } & Coefficient of friction \\
\hline Oil with Paraffin & 6.78 \\
Oil with Polyethylene Wax & 6.76 \\
\hline \hline
\end{tabular}

TABLE II

ANOVA TEST, COMPARISON BETWEEN THE COEFFICIENTS OF FRICTION OF THE MIXTURE OF SESAME OIL WITH PARAFFIN AND POLYETHYLENE WAX.

\begin{tabular}{lccccc}
\hline \hline & $\begin{array}{c}\text { Sum of } \\
\text { squares }\end{array}$ & $\mathrm{gl}$ & $\begin{array}{c}\text { Quadrati } \\
\mathrm{c} \text { half }\end{array}$ & $\mathrm{F}$ & Significance \\
\hline Inter-groups & 0.001 & 1 & 0.001 & 0.007 & 0.937 \\
Intra-groups & 0.339 & 4 & 0.085 & & \\
Total & 0.340 & 5 & & & \\
\hline \hline
\end{tabular}

TABLE III

ANOVA TEST, COMPARISON BETWEEN THE COEFFICIENT OF FRICTION OF SESAME OIL AND MIXTURES WITH PARAFFIN AND POLYETHYLENE WAX.

\begin{tabular}{lccccc}
\hline \hline & $\begin{array}{c}\text { Sum of } \\
\text { squares }\end{array}$ & gl & $\begin{array}{c}\text { Quadrati } \\
\text { c half }\end{array}$ & F & Significance \\
\hline Inter-groups & 0.223 & 2 & 0.111 & 1.972 & 0.220 \\
Intra-groups & 0.339 & 6 & 0.056 & & \\
Total & 0.562 & 8 & & & \\
\hline \hline
\end{tabular}

\section{B. Extreme Pressure Properties (EP)}

The performance of the additives (paraffin and polyethylene wax) in sesame oil was evaluated in conditions of Extreme Pressure, which was done in terms of Load Prior to Visible Wear and Welding Point. Figure 3 shows the behavior of the average diameter of the wear fingerprint (DPH in $\mathrm{mm}$ ) as a function of the applied load, observing that the load prior to visible wear is at $24 \mathrm{Kg}-\mathrm{F}(235 \mathrm{~N})$ for sesame oil with paraffin and at $20 \mathrm{Kg}-\mathrm{F}(196 \mathrm{~N})$ for sesame oil with polyethylene wax. 


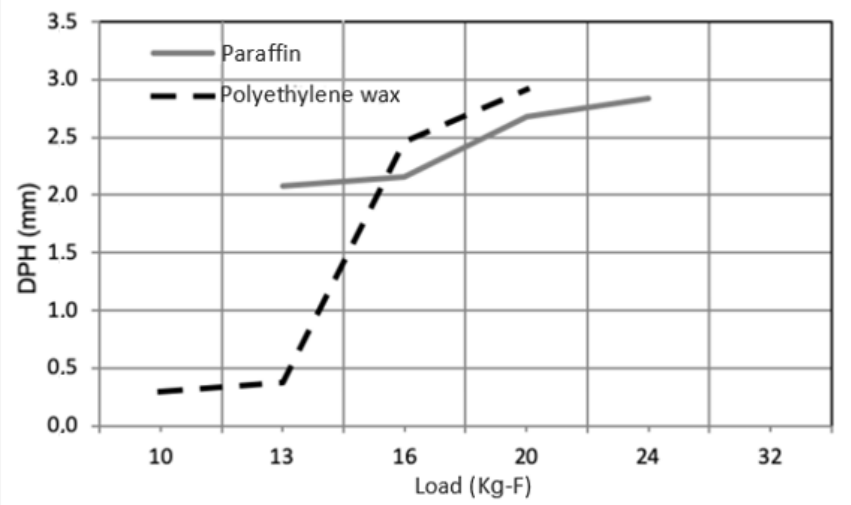

Fig. 3. Average diameter of the wear fingerprint as a function of the applied load, extreme pressure test.

The images presented in Figure 4 show the size of the footprint produced by the applied load, and at the same time the appearance of wear outside the circumference resulting from the test.
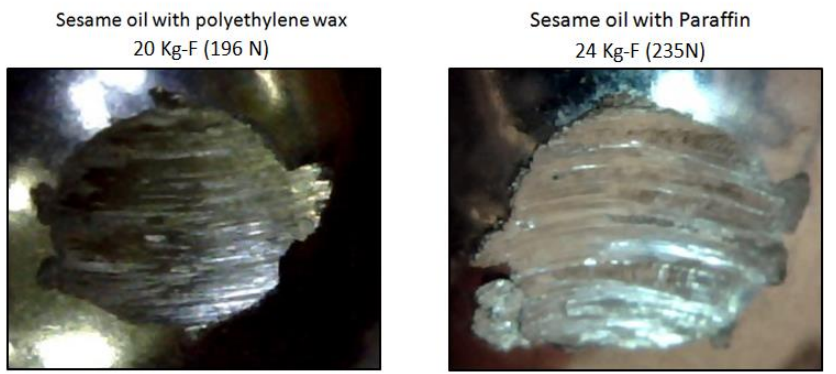

Fig. 4. Fingerprint diameter image. Load Prior to Visible Wear.

In relation to the welding point, it was found that for the mixture of sesame oil with paraffin this point is at a load of 32 $\mathrm{Kg}-\mathrm{F}(314 \mathrm{~N})$, while for the polyethylene wax it is at $24 \mathrm{Kg}-\mathrm{F}$ $(235 \mathrm{~N})$, as it is presented in the images of Figure 5, at the same time an evident deformation in the spheres due to the applied load is shown.
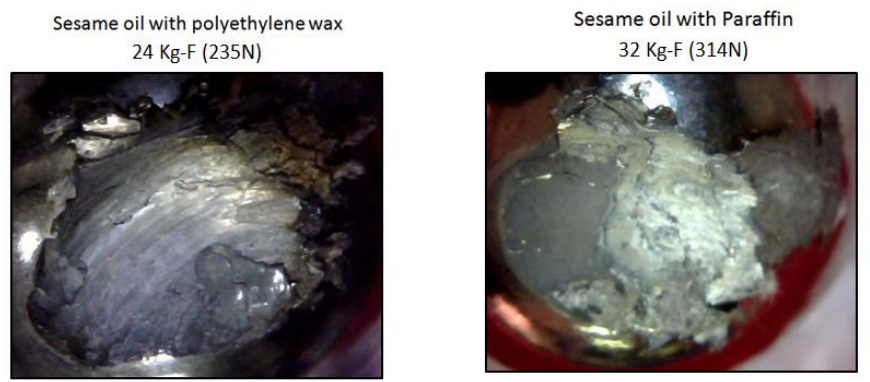

Fig. 5. Image of the welding point for sesame oil with the additives.

When comparing the results obtained in the Extreme Pressure test for sesame oil using Polyethylene Wax and Paraffin as additives (Figure 6), it was found that the latter presents a greater resistance to the applied load, giving the point of welding at $32 \mathrm{Kg}-\mathrm{F}(314 \mathrm{~N})$, while for the polyethylene wax it is at a load of $24 \mathrm{Kg}-\mathrm{F}(235 \mathrm{~N})$.

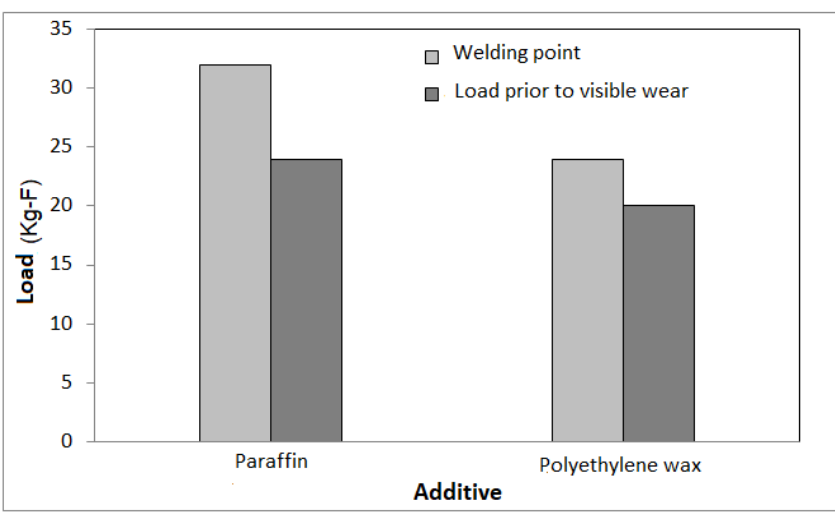

Fig. 6. Extreme Pressure Properties.

In previous investigations, it was found that for the Extreme Pressure test the sesame oil has a welding point of $235 \mathrm{~N}$ [23]. With the results obtained by adding additives it was demonstrated that the addition of paraffin improves the lubricating power of the oil for the Extreme Pressure test, reaching a welding point at $314 \mathrm{~N}$. On the other hand, the addition of polyethylene wax does not present changes in the load supported by the lubricating oil. This is due to paraffin having a molecular weight between 400-1000 [22], which is why it can interact and react more quickly and easily than polyethylene wax.

\section{CONCLUSIONS}

The spheres lubricated with sesame oil and polyethylene wax have the smallest average diameter of the wear fingerprint, possibly, because of the composition of the additive and its slightly branched structure the interaction between the polar heads and the branched chains of polyethylene wax increases, decreasing the metal-metal contact and, therefore, the resulting fingerprint diameter.

In relation to the coefficient of friction (f), the results, according to the ANOVA test, show that there is no significant difference between the values obtained for pure sesame oil and with the additives.

In the Extreme Pressure test it was found that paraffin presents a higher resistance to the applied load, giving the welding point at $32 \mathrm{Kg}-\mathrm{F}(314 \mathrm{~N})$, while for polyethylene wax it is at a load of $24 \mathrm{Kg}-\mathrm{F}(235 \mathrm{~N})$. At the same time when compared with the welding point of the pure sesame oil $(235 \mathrm{~N})$, an improvement in this property of the oil with paraffin is evidenced.

From these results it can be concluded that the yield of sesame oil as a lubricant can be improved by mixing it with paraffin and polyethylene wax; however, the percentages added must be determined correctly.

\section{REFERENCES}

[1] A. Adhvaryu, Z. Liu, S.Z. Erhan, "Synthesis of novel alkoxylatedtriacylglycerols and their lubricant base oil properties", Industrial Crops and Products, vol. 21, pp. 113-119. 2005. DOI: 10.1016/j.indcrop.2004.02.001

[2] Salih, N., Salimon, J., Yousif, E. "Synthetic bio-lubricant basestocks based on environmentally friendly raw materials". 
Journal of King Saud University - Science, vol. 24, pp 3221-3226. 2012. DOI: https://doi.org/10.1016/j.jksus.2011.02.003

[3] P. Nagendramma, S. Kaul. "Development of ecofriendly/biodegradable lubricants: An overview". Renewable and Sustainable Energy Reviews, vol 16, pp. 764- 774. 2012. doi:10.1016/j.rser.2011.09.002

[4] Jayadas, N., Nair, K.P. Coconut oil as base oil for industrial lubricants - evaluation and modification of thermal, oxidative and low temperature properties. Tribology international, vol. 39, pp. 873-878. 2006. Doi: https://doi.org/10.1016/j.triboint.2005.06.006

[5] Syahrullail, S., Hariz, M., Abdul Hamid, M., Abu Bakar, A., "Friction Characteristic of Mineral Oil Containing Palm Fatty Acid Distillate using Four Ball Tribo-tester", Procedia Engineering, vol. 68, pp.166 - $171.2013 . \quad$ doi: https://doi.org/10.1016/j.proeng.2013.12.163

[6] Choi, U., Ahn, B., Kwon, O., and Chun, Y., "Tribological behavior of some antiwear additives in vegetable oils", Tribology International, vol. 30(9), pp. 677-683. 1997. Doi https://doi.org/10.1016/S0301-679X(97)00039-X

[7] Gong, Q., Wanren, H., Liu, W. “ The tribological behavior of thiophosphates as additives in rapeseed oil". Tribology International, vol. 36, pp. 733-738. 2003. doi: https://doi.org/10.1016/S0301-679X(03)00053-7

[8] Jayadas, N., Prabhakaran, N., Ajithkumar G. "Tribological evaluation of coconut oil as an environment-friendly lubricant". Tribology International, vol 40, pp. 350-354. 2007. doi: https://doi.org/10.1016/j.triboint.2005.09.021

[9] A. Adhvaryu, S. Erhan, J. Perez, "Tribological studies of thermally and chemically modified vegetable oils for use as environmentally friendly lubricants", Wear, vol 257, pp. 359-367. 2004. doi: https://doi.org/10.1016/j.wear.2004.01.005

[10] Quinchia, L., Delgado, M., Reddyhoff, T. Gallegos, C., Spikes, H. "Tribological studies of potential vegetable oil-based lubricants containing environmentally friendly viscosity modifiers". Tribology International, vol. 69, pp. 110-117. 2014. Doi: https://doi.org/10.1016/j.triboint.2013.08.016

[11] Xiangqiong, Z., Heyang, S., Wenqi, R., Zhongyia, H., Tianhuia, R. "Tribological study of trioctylthiotriazine derivative as lubricating oil additive". Wear, vol. 258, pp. 800-805. 2005. Doi: https://doi.org/10.1016/j.wear.2004.09.067

[12] Xiangqiong, Z., Li, J., Xuedong, W., Ren, T., Liu, W. "The tribological behaviors of hydroxyl-containing dithiocarbamatetriazine derivatives as additives in rapeseed oil". Tribology International, vol. 40, pp. 560-566. 2007. Doi: https://doi.org/10.1016/j.triboint.2006.05.005

[13] Xiangqiong, Z., Wu, H., Yi, H., Ren, T. "Tribological behavior of three novel triazine derivatives as additives in rapeseed oil". Wear, vol. 262, pp. 718-726. 2007. Doi: https://doi.org/10.1016/j.wear.2006.08.004

[14] Weijiu, H., Dong, J., Wu, G., Zhang, C. "Tribological performance and action mechanism of S-[2-(acetamido) thiazol-1-yl] dialkyl dithiocarbamate as additive in rapeseed oil". Wear, vol. 256, pp. 1106-1113. 2004. Doi: https://doi.org/10.1016/S00431648(03)00532-5

[15] Yubin, S., Litian, H., Qunji, X. “ Tribological properties and action mechanism of N,N-dialkyl dithiocarbamate-derived S-hydroxyethyl borate esters as additives in rapeseed oil". Wear, vol. 266, pp. $917-$ 924. 2009. Doi: https://doi.org/10.1016/j.wear.2008.12.004

[16] Weijiu, H., Dong, J., Wu, G., Zhang, C. "A study of S-[2(acetamido) benzothiazol-1-yl]N,N-dibutyl dithiocarbamate as an oil additive in liquid paraffin". Tribology International, vol. 37, pp. 71-76. 2004. Doi: https://doi.org/10.1016/j.triboint.2003.07.001

[17] Li, J., Zhang, Y., Ren, T., Liu, W., Fu, X. "Tribological evaluation of S-(1H-benzotriazole-1-yl) methyl N,N-dialkyldithiocarbamates as additives in rapeseed oil". Wear, vol. 253, pp. 720-724. 2002. Doi: https://doi.org/10.1016/S0043-1648(02)00227-2

[18] Shahabuddin, M., Masjuki, H., Kalam, M., Bhuiya, M., Mehat, H. "Comparative tribological investigation of bio-lubricant formulated from a non-edible oil source (Jatropha oil)". Industrial Crops and Products, vol. 47, pp. 323- 330. 2013. Doi: https://doi.org/10.1016/j.indcrop.2013.03.026

[19] Sathwik, K. R., Jayadas, N. H. y Kailas, S."Natural Oil-Based Lubricants",in Green Tribology, Nosonovsky, M.; Bhushan, B., Eds. Springer, Berlin Heidelberg, pp. 287-328. 2012
[20] Essential oils. Ácidos grasos encontrados en el aceite de sésamo.[Online]. Available: http://www.essentialoils.co.za/sesameoil-analysis.htm

[21] Bart, J. C., Gucciardi, E. y Cavallaro, S. "Chemical transformations of renewable lubricant feedstock", in Biolubricants Science and technology, Woodhead Publishing Limited, vol. 46, pp. 249-350. 2013. Doi: $10.1533 / 9780857096326.249$

[22] Multiceras Blending With You. Aplicaciones.[Online] Avalaible: http://multiceras.com/es/plasticos

[23] Delgado, A., Aperador, W. "Estudio Comparativo del Poder Lubricante y Estabilidad Oxidativa entre el Aceite de Ajonjolí y Aceite Mineral 360". Información tecnológica, vol. 25(4), pp.79-90. 2014. Doi: http://dx.doi.org/10.4067/S0718-07642014000400011

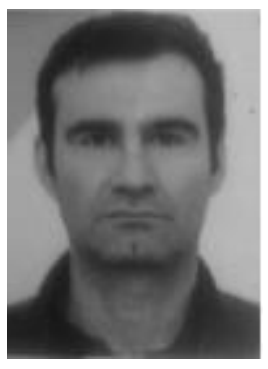

Arnoldo Emilio Delgado Tobón, Performed his undergraduate studies in Mechanical Engineering in the Universidad Nacional of Colombia (UNAL) and MSc in Mechanical Engineering from the Universidad de Los Andes, Bogotá, Colombia. He is an Associate Professor on Mechatronic Engineering Program at Universidad Militar Nueva Granada, Bogotá,

ORCID: 0000-0002-8743-8958

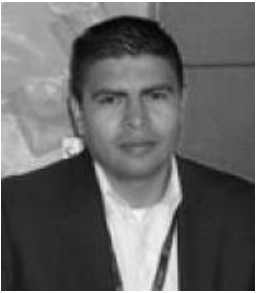

William Arnulfo Aperador Chaparro, has a PhD. in Materials Engineering, a MSc in Mechatronic Engineering and he is titular professor on Mechatronic Engineering Program at Universidad Militar Nueva Granada, Bogotá ORCID: 0000-0001-9006-0020

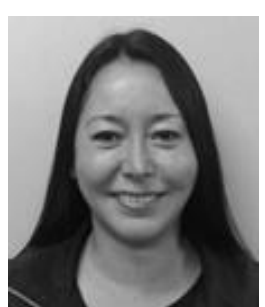

Esperanza Rodríguez Carmona, was born in Pereira (Colombia). She performed her undergraduate studies in Mechanical Engineering (1997) from the Universidad Tecnológica de Pereira (UTP). She is an Associate Professor on Industrial Engineering program at Universidad Militar Nueva Granada, Bogotá ORCID: 0000-0003-2915-6829 